COUNSENESIA
Indonesian Journal of Guidance and Counseling
$2(1)(2021): 52-60$
www.ejournal.utp.ac.id /index.php/CIJGC

\title{
PENGARUH KONSELING BEHAVIORAL TEKNIK MODELLING TERHADAP NEED OF DEFERENCE DITINJAU DARI STATUS ANAK DALAM KELUARGA
}

\begin{tabular}{|c|c|}
\hline & $\begin{array}{c}\text { Rofi'ud Darojatin Nisaa } \\
\text { Universitas Panji Sakti Singaraja } \\
\text { Email: rofiuddarajatun@gmail.com }\end{array}$ \\
\hline Info Artikel & Abstrak \\
\hline $\begin{array}{l}\text { Riwayat Artikel } \\
\text { Diterima: } \\
\text { 19 April } 2021 \\
\text { Disetujui: } \\
\text { 30 April } 2021 \\
\text { Publikasi: } \\
\text { Juni 2021 }\end{array}$ & $\begin{array}{l}\text { Penelitian ini bertujuan untuk menganalisis pengaruh konseling behavioral teknik } \\
\text { modelling terhadap need of deference ditinjau dari status anak dalam keluarga. } \\
\text { Penelitian ini termasuk penelitian eksperimen, subjek penelitian adalah siswa kelas XI } \\
\text { SMA Laboratorium Undiksha yang dilakukan dengan menggunakan teknik purposive } \\
\text { sampling. Data penelitian dikumpulkan menggunakan kuesioner dan dianalisis } \\
\text { menggunakan anava dua jalur dan } \mathrm{t} \text {-scheffe. Hasil penelitian menunjukkan bahwa: (1) } \\
\text { terdapat perbedaan need of deference antara siswa yang berstatus anak sulung dengan } \\
\text { anak bungsu }(\mathrm{F}=9.961 ; \mathrm{p}<0,05),(2) \text { terdapat perbedaan need of deference antara siswa } \\
\text { dengan status anak sulung dan anak bungsu setelah mengikuti teknik modeling } \\
(\mathrm{t}=6.735 ; \alpha<2.048) \text {. }\end{array}$ \\
\hline
\end{tabular}

Kata Kunci: teknik modelling,need of deference, status anak

\begin{abstract}
This study aims to analyze the effect of behavioral counseling modeling techniques on the need of difference in terms of the child's status in the family. This research includes experimental research, the research subjects are students of class XI SMA Laboratorium Undiksha which was conducted using purposive sampling technique. Research data were collected using a questionnaire and analyzed using two-way ANOVA and t-scheffe. The results showed that: (1) there was a difference in need of deference between students with the status of the eldest child and the youngest child $(\mathrm{F}=9.961 ; \mathrm{p}<0.05),(2)$ there was a difference in need of deference between students with the status of the eldest child and the youngest child. youngest after following the modeling technique $(\mathrm{t}=6.735 ;<2.048)$.
\end{abstract}

Keywords: modeling technique, need of difference, child status

(C) 2021 Universitas Tunas Pembangun Surakarta

ISSN: 2746-3532 (Online) 


\section{PENDAHULUAN}

Pendidikan merupakan salah satu bentuk upaya yang mendukung terciptanya sumber daya manusia yang berkualitas. Pendidikan yang diharapkan tidak hanya terfokus pada aspek kognitif semata tetapi juga aspek non kognitif. Kedua aspek ini memberi pengaruh yang cukup besar terhadap perkembangan peserta didik. Pendidikan kognitif mengembangkan aspek intelektual, sedangkan aspek non kognitif membantu mengembangkan sikap, keterampilan maupun kepribadian peserta didik.

Pengembangan sikap, keterampilan maupun kepribadian siswa adalah salah satu tanggung jawab dari seorang guru bimbingan konseling. Hal ini sesuai dengan Peraturan Menteri Pendidikan dan Kebudayaan Republik Indonesia Nomor 111 Tahun 2014 tentang bimbingan dan konseling pada pendidikan dasar dan pendidikan menengah pada pasal 1 ayat 1 yang berbunyi "Bimbingan dan Konseling adalah upaya sistematis, objektif, logis, dan berkelanjutan serta terprogram yang dilakukan oleh konselor atau guru Bimbingan dan Konseling untuk memfasilitasi perkembangan peserta didik/ konseli untuk mencapai kemandirian dalam kehidupannya".

Berkaitan dengan hal tersebut, seorang guru bimbingan konselingdiharapkan mampu merancang layanan-layanan yang bertujuan untuk mengembangkan sikap, keterampilan maupun kepribadian siswa sehingga mencapai kemandirian dalam kehidupannya. Menurut Murray (dalam Hall \& Lindzey, 1970:168), Kepribadian terbentuk dari suatu proses yang menyusun dan mengendalikan diri individu yang berfungsi untuk menyatukan dorongan yang bertentangan dengan pemenuhan kebutuhan dan rencanan untuk pencapaian tujuan personal. Kepribadian harus merefleksikan tidak hanya elemen perilaku bertahan dan berulang namunjuga harus merefleksikan apa yang unik dan asing.Tidak ada satupun proses dapat difahami tanpa merujuk pada sesuatu yangmenyebabkannya dan tanpa merujuk pada tujuan dan harapan pemain, serta rancangannya untukmasa depan.

Berdasarkan pendapat tersebut dapat dikatakan bahwa dalam membentuk kepribadian siswa di sekolah diharapkan siswa mampu melalui proses dalam mengendalikan keinginannya demi memenuhi kebutuhannya sebagai seorang siswa sehingga terbentuk kebiasaan yang dapat membantu siswa tersebut memenuhi kewajibannya sebagai siswa sekaligus mencapai cita-cita dimasa depan. Bersantai, bersikap egois, tidak memikirkan perasaan orang lain dan berperilaku sekehendak hati merupakan keinginan-keinginan yang harus dikendalikan. Sedangkan kebutuhan yang dimaksud disini salah satunya adalah kebutuhan menaati perintah atau aturan (Need of Deference) yang diharapkan setelah terpenuhinya kebutuhan tersebut siswa tidak hanya mampu memenuhi kewajibannya sebagai siswa untuk berperilaku taat, disiplin dan mampu menghormati orang lain, melainkan juga memiliki kebiasaan yang akan terbawa meskipun sudah lulus dari sekolah.

Kamus Oxford (2008:116) menyatakan bahwa "deference: behaviour that shows you respect" yang dapat didefinisikan sebagai berikut "deference adalah perilaku yang menunjukkan rasa hormat". Menurut Edward (dalam Suarni, 2014:27) Need of deference ialah kebutuhan menaati perintah atau aturan meliputi menerima saran-saran dari orang lain, mendapat keterangan apa yang dipikirkan orang lain, mengikuti petunjuk-petunjuk dan mengerjakan apa yang diharapkan. Sedangkan Deference (DEF) yang dimaksudkan dalam tes Psikologi Edward Personal Preference Schedule (EPPS) yaitu kebutuhan untuk mentaati perintah dan peraturan (Ferara 1996:23). Berdasarkan definisi di atas menyangkut deferencemaka dapat disimpulkan bahwa Need ofDeference adalah kebutuhan mentaati perintah atau aturan dan menghormati orang lain, meliputi menerima saran-saran dari 
orang lain, mendapat keterangan apa yang dipikirkan orang lain, mengikuti petunjukpetunjuk dan mengerjakan apa yang diharapkannya.

Melalui layanan bimbingan konseling diharapkan guru bimbingan konseling mampu membantu siswa dalam mengendalikan keinginan-keinginan negatif siswa demi memenuhi Need of deference, sehingga dapat membentuk perilaku dan kebiasaan positif yang dapat mempermudah siswa dalam mencapai cita-citanya. Berdasarkan hasil pengamatan di kelas XI SMA Laboratorium UNDIKSHA Singaraja, terlihat beberapa siswa yang menunjukkan perilaku seperti mau mengikuti petunjuk-petunjuk yang diberikan oleh guru, mau mengerjakan tugas sesuai dengan yang diharapkan, mau menerima saran dari orang lain, mentaati aturan yang berlaku, serta mau mengerjakan tugas-tugas sesuai dengan yang diperintahkan oleh guru. Para siswa yang memiliki ciri tersebut mengindikasikan bahwa Need of Deference dapat dipenuhi dengan baik. Akan tetapi terdapat pula siswa yang cenderung tidak bisa diatur bertindak semena-mena, tidak mau menerima saran dari orang lain, tidak menghiraukan petunjuk-petunjuk yang diberikan oleh guru, tidak mau mengerjakan tugas serta berperilaku yang tidak sesuai dengan aturan yang berlaku di sekolah. Perilaku-perilaku tersebut disebabkan oleh pemikiran siswa yang beranggapan bahwa indikator-indikator yang diharapkan hanyalah sebuah kewajiban yang harus dilakukan oleh seorang siswa selama di sekolah. Padahal siswa SMA memiliki kewajiban untuk memenuhi tugas-tugas perkembangan, salah satunya adalah mencapai kematangan dalam sistem etika dan nilai yang erat kaitannya dengan pemenuhan need of deference.

Tugas-tugas perkembangan tersebut dapat terpenuhi dan berjalan dengan lancar apabila siswa mampu menjadikan indikator-indikator need of deference tidak hanya sebagai kewajiban yang harus dipenuhi melainkan juga sebuah kebutuhan yang memang akan diperlukan untuk menjalani kehidupan kedepannya di masyarakat. Upaya yang dilakukan oleh pihak sekolah untuk meningkatkan Need of deference siswa sangat terlihat jelas pada peraturan yang diberlakukan dan disertai dengan sanksi-sanksi pada setiap pelanggaran tata tertib. Selain pengadaan peraturan sekolah upaya lain yang telah dilakukan pihak sekolah adalah melalui layanan Bimbingan Konseling. Bimbingan Konseling (BK) merupakan bagian dari sekolah yang senantiasa memberikan layananlayanan kepada peserta didik dalam upaya membantu peserta didik agar mampu berkembang secara optimal sesuai dengan potensi yang mereka miliki.

Sangat disayangkan upaya yang dilakukan oleh pihak sekolah belum menunjukkan hasil yang maksimal. Hal ini dikarenakan pelaksanaan layanan bimbingan konseling yang diberikan pada siswa tanpa disertai teknik, sehingga bersifat monoton dan menyebabkan siswa tidak tertarik serta cepat merasa bosan. Faktor penyebab yang lainnya adalah kebiasaan siswa yang terbentuk berdasarkan status anak dalam keluarga. Berdasarkan hasil wawancara sementara dengan salah satu guru bimbingan konseling di SMA Laboratorium UNDIKSHA mengenai permasalahan yang dialami oleh siswa, diperoleh hasil bahwa siswa memiliki Need of deference yang berbeda-beda dapat ditinjau dari status anak dalam keluarga. Keberagaman tersebut diduga karena siswa memiliki kebiasaan-kebiasaan yang terbentuk dari lingkungan keluarga yang disebabkan status siswa sebagai anak dalam keluarga. Tanpa disadari kedudukan anak yang berbeda dalam keluarga biasanya akan mempengaruhi pemenuhan dan peningkatan Need of deference seseorang. Hal ini dikarenakan berbedanya status anak maka akan berbeda pula perlakuan atau asuhan yang diberikan orang tua, sehingga akan membentuk kebiasaan atau kepribadiaan yang berbeda pula pada si anak tersebut. Dengan adanya perbedaan perlakuan pada masing-masing status anak, maka akan membentuk kebiasaan yang berbeda pula, sehingga Need of 
deference masing-masing status anakpun secara tidak langsung turut berbeda pula.

Menurut Hurlock (1990) Urutan kelahiran seorang anak dalam sebuah keluarga biasanya memiliki perbedaan perlakuan baik dari orang tua maupun saudara, demikian pula harapan-harapan yang diberikan terhadap mereka. Sedangkan menurut Gunarsa (2004:174) setiap anak dalam keluarga mempunyai posisinya sendiri-sendiri. Setiap kedudukan atau status menyebabkan tanggungjawab dan konsekuensi yang berbeda. Hal ini bisa disebabkan oleh kebudayaan maupun sikap orangtua yang berbeda.

Status anak dapat dibagi menjadi beberapa yaitu, anak tiri, anak tunggal, anak sulung, anak tengah, anak bungsu, dan ada pula anak pungut. Berdasarkan studi pendahuluan di kelas XI SMA Laboratorium UNDIKSHA sebagian besar siswa berstatus sebagai anak sulung dan anak bungsu, hal ini mungkin dikarenakan adanya modernisasi dalam perencanaan kehidupan berkeluarga. Seperti yang kita ketahui pemerintah melakukan upaya dalam menanggulangi kepadatan penduduk melalui program KB (Keluarga Berencana), sehingga dalam sebuah keluarga (pasangan suami istri) biasanya hanya memiliki dua anak saja. Dikarenakan hal tersebut dalam penelitian ini hanya menekankan pada status khas anak sulung dan anak bungsu saja.

Pengamatan yang dilakukan di kelas XI SMA Laboratorium UNDIKSHA memperoleh hasil bahwa siswa yang memiliki status khas sebagai anak sulung cenderung memiliki sifat dan kepribadian layaknya seorang boss (bossy) yang berkuasa, senang mengatur teman-temannya dalam mengerjakan tugas-tugas sekolah, namun terlihat lebih dewasa dalam menyelesaikan masalah-masalahnya, sehingga berpikir terlebih dahulu sebelum bertindak dan terkadang mau mempertimbangkan saran dari orang lain. Berbeda halnya dengan anak bungsu yang memiliki sifat malas dalam mengerjakan tugas-tugas, cenderung bergantung pada orang lain, tidak mau mendengarkan saran dari orang lain dan cenderung egois.

Berkaitan dengan hal tersebut peneliti tertarik menggunakan teori dan teknik konseling yang diduga akan efektif dalam membantu siswa dalam membentuk kebiasan untuk memenuhi Need of deference. Salah satu teori yang dapat digunakan adalah konseling behavioral. Menurut Corey (2003:198) konseling Behavioral adalah konseling yang menekankan pada tingkah laku manusia yang pada dasarnya dibentuk dan ditentukan oleh lingkungan dan segenap tingkah lakunya itu dipelajari atau diperoleh karena proses latihan. Terdapat berbagai teknik dalam konseling Behavioral yang dapat digunakan dan masing-masing teknik pastilah memiliki kebaikan dan juga kelemahnnya. Teknik modelling diprediksi mampu membantu siswa dalam membentuk kebiasaan untuk memenuhi Need of deference siswa, karena teknik modelling menampilkan contoh-contoh individu yang dapat dijadikan teladan bagi siswa dalam memperbaiki perilaku mereka. Menurut Komalasari (2011:176) modelling merupakan belajar melalui observasi dengan menambahkan atau mengurangi tingkah laku yang teramati, menggeneralisir berbagai pengamatan sekaligus melibatkan proses kognitif. Modelling mengubah tingkah laku lama yaitu dengan meniru tingkah laku model yang dapat diterima lingkungan sosial.

Pemilihan konseling behavioral teknik modelling juga dikarenakan keberhasilan yang diraih oleh penelitian terdahulu. Adawiyah (2012), dalam penelitiannya yang berjudul Pengembangan Model Konseling Behaviour dengan Teknik Modeling untuk Meningkatkan Kemandirian Belajar Siswa SMPN 4 Wanasari Brebes. Hasil secara empiris bahwa model konseling behavior dengan teknik modeling efektif dapat meningkatkan kemandirian belajar siswa kelas VIII SMP Negeri 4 Wanasari Brebes.

Berdasarkan uraian diatas serta fakta yang ditemukan di lapangan, maka rumusan masalah dalam penelitian ini adalah (1) apakah terdapat perbedaan Need of deference 
antara siswa yang berstatus sebagai anak sulungdengan siswa yang berstatus sebagai anak bungsu?(2) apakah terdapat perbedaan Need of deference antara siswa yang berstatus sebagai anak sulung dengan siswa yang berstatus sebagai anak bungsu setelah mengikuti konseling behavioral teknik modelling?

\section{METODE}

Penelitian ini merupakan penelitian eksperimen.Populasi target dalam penelitian ini adalah seluruh siswa Kelas XI SMA Laboratorium Undiksha Singaraja tahun pelajaran 2015/2016 yang berjumlah 162 orang siswa. Sedangkan pengambilan sampel dalam penelitian ini dilakukan dengan teknik purposive sampling. Peneliti akan mengambil sampel individu sebanyak 60 orang, yaitu 30 orang siswa berstatus sebagai anak sulung dan 30 siswa berstatus sebagai anak bungsu.

Data pada penelitian ini dikumpulkan menggunakan kuesioner Need of Deference. Need of deference memiliki tigaaspek (1) mendapatkan keterangan apa yang dipikirkan orang lain. (2) menerima saran dari orang lain. (3) mengikuti petunjuk dan mengerjakan apa yang diharapkannya. Dari ketiga aspek tersebut dikembangkan lagi menjadi beberapa indikator. Contohnya pada aspek menerima saran dari orang lain, dikembangkan menjadi 2 indikator yaitu (1) mau mendengarkan pendapat orang lain, (2) dengan senang hati menerima kritikan dari orang lain. Sedangkan contoh bentuk pernyataan dalam kuesioner yaitu: (1) saya akan memberikan kesempatan pada teman yang ingin memberikan pendapat , (2) saya akan menerima pendapat teman saya meskipun pendapat teman saya berbeda dengan pendapat saya.

Uji validitas kuesioner dilaksanakan dalam beberapa tahapan, dimulai dari uji validitas isi yang dimintakan penilaian dari expert judgment. Penilaian dilakukan oleh dua penilai/pakar (judges). Berdasarkan hasil rekapitulasi penilaian oleh judges dan untuk mengetahui tingkat validitasnya, maka data dalam tabel rekapitulasi penilaian judges di rekap ke dalam tabel formula Gregory. Berdasarkan uji validitas, maka instrumen tersebut tergolong dalam kategori "sangat tinggi" kevaliditasannya. Sehingga seluruh butir instrumen need of deference dapat dikatakan valid, sehingga layak untuk di uji cobakan dilapangan.

Setelah diketahui validitas isi, maka dilanjutkan dengan uji validitas butir tes. Uji empiris dalam bentuk uji coba terpakai bertujuan untuk memperoleh tingkat validitas instrumen. Instrumen yang valid dapat mengukur apa yang semestinya diukur. Uji coba terpakai berarti kuesioner yang telah dinyatakan relevan dan memenuhi persyaratan validitas isi, langsung digunakan untuk mengumpulkan data kuantitatif. Dengan demikian diadakan uji coba terlebih dahulu terhadap kuesioner Need of deference siswa, kemudian hasil uji coba tersebut dianalisis terkait validitas dari masing-masing butir yang ada sebagai alat pengambilan data. Untuk mengukur validitas dari kuesioner, dilakukan dengan cara mengkorelasi skor tiap butir kuesioner terhadap total skor pada setiap faktor dari masingmasing responden yang akan diuji coba, dapat dihitung dengan menggunakan rumus korelasi product moment dari Pearson.

Selanjutnya dilakukan uji reliabilitas instrumen. Reliabilitas mengacu pada konsistensi hasil pengukuran yang ditunjukkan oleh instrumen tersebut. Instrumen yang tinggi akan memberikan hasil yang relatif sama, sekalipun instrumen tersebut digunakan dalam kurun waktu yang berbeda dan dengan sampel responden yang berbeda juga. Untuk mengukur tingkat keajegan tes (kuesioner) digunakan perhitungan alpha cronbach.Dari hasil analisis validitas ternyata 40 butir valid. Berdasarkan data pada uji validitas untuk 
semua pernyataan kuesioner need of deference yang valid diperoleh koefisien reliabilitas sebesar 0,939 yang kemudian dihubungkan dengan kriteria yang dibuat oleh Guilford, ternyata butir kuesioner need of deference yang diuji cobakan memiliki derajat reliabilitas tergolong "tinggi".

Selain kuesioner peneliti juga membuat pedoman wawancara dan observasi sebagai penunjang/ metode pelengkap untuk mengetahui apakah hasil kuesioner yang telah diisi oleh siswa telah sesuai dengan kondisi yang sebenarnya. Analisis data yang digunakan yaitu Analisis Anava Dua Jalur dan $t$-scheffe.

\section{HASIL DAN PEMBAHASAN}

Dari hasil analisis data yang diperoleh telah terbukti bahwa terdapat perbedaan efektifitas konseling behavioral teknik modelling terhadap need of deference ditinjau dari status anak dalam keluarga. Hal ini ditunjukkan dengan hasil sebagai berikut: Hasil uji hipotesis 1 menunjukkan bahwa $F_{\text {hitung }}>F_{\text {tabel }}(9.961>4.00)$ dengan taraf signifikansi $(p)<$ 0,05 sehingga hipotesis alternatif (H1) yang berbunyi“terdapat perbedaan Need of deference antara siswa yang berstatus sebagai anak sulungdengan siswa yang berstatus sebagai anak bungsu", diterima.Rata-rata Need of deference kelompok anak sulung $(\overline{\mathrm{X}}=$ 164.933) lebih tinggi daripada kelompok anak bungsu ( $\bar{X}=158.533)$.

Hasil uji hipotesis 2 menunjukkan bahwa $t_{\text {hitung }}>t_{(\mathrm{dk} ; \alpha)}(6.735>2.048)$ sehingga hipotesis alternatif (H1) yang berbunyi "terdapat perbedaan Need of deference antara siswa yang berstatus sebagai anak sulung dengan siswa yang berstatus sebagai anak bungsu setelah mengikuti konseling behavioral teknik modelling", diterima. Rata-rata Need of deference kelompok siswa anak sulung $(\overline{\mathrm{X}}=172.667)$ lebih tinggi daripada kelompok anak bungsu $(\overline{\mathrm{X}}=160.867)$ setelah dilakukan teknik modellng.

Tabel 01. Hasil Penelitian

\begin{tabular}{|c|c|c|c|c|c|c|}
\hline \multirow{2}{*}{\multicolumn{2}{|c|}{ Intervensi }} & \multicolumn{2}{|c|}{ Pre test } & \multicolumn{2}{|c|}{ Post test } & \multirow[b]{2}{*}{ Uji ANAVA } \\
\hline & & \multirow{2}{*}{$\begin{array}{c}\text { Mean } \\
164.933\end{array}$} & \multirow{2}{*}{$\begin{array}{c}\text { Standar } \\
\text { Deviasi }\end{array}$} & \multirow{2}{*}{$\begin{array}{c}\text { Mean } \\
172.667\end{array}$} & \multirow{2}{*}{$\begin{array}{c}\begin{array}{c}\text { Standar } \\
\text { Deviasi }\end{array} \\
6.007\end{array}$} & \\
\hline Konseling & Anak Sulung & & & & & \\
\hline Behavioral & Anak Bungsu & 158.533 & 5.858 & 160.867 & 6.691 & $F_{\text {hitung }}>\mathrm{F}_{\text {tabel }}$ \\
\hline $\begin{array}{l}\text { Teknik } \\
\text { Modelling }\end{array}$ & $t$-scheffe & & & & & \\
\hline
\end{tabular}

Need of Deference dapat dipengaruhi oleh beberapa faktor, salah satunya adalah status anak dalam keluarga.Setiap anak dalam keluarga memiliki status yang berbedabeda. Urutan kelahiran seorang anak dalam sebuah keluarga biasanya menentukan perlakuan baik dari orang tua maupun saudara, demikian pula harapan-harapan yang diberikan terhadap mereka. Menurut Sujanto (2008:49) anak-anak menempati kedudukan yang khas dalam keluarga, sehingga pada umumnya akan menunjukkan tipe-tipe yang khas pula bila dibandingkan dengan anak-anak yang lain, sehingga memerlukan perlakuan, pelayanan atau pemomongan yang lain pula, agar tidak merugikan anak itu sendiri, merugikan anak yang lain ataupun merugikan keluarga.

Sikap dan perilaku anak yang berstatus sebagai anak sulung tentu akan berbeda dengan sikap dan perilaku yang berstatus sebagai anak bungsu. Hal ini tentu saja dipengaruhi oleh perbedaan perlakuan yang diberikan oleh orang tua yang secara tidak langsung akan membentuk pribadi anak menjadi berbeda-beda pula. Anak sulung dituntut untuk lebih mandiri dibandingkan status anak yang lain. Orang tua kerap lebih tegas 
kepada anak sulung karena dianggap bertanggung jawab terhadap adiknya. Orang tua membentuk anak sulung sebagai individu yang mampu membuat keputusan sendiri sebagai bentuk rasa percaya diri dan tanggung jawab, hanya saja kepercayaan yang diberikan orang tua tersebut membuat anak sulung kerap tidak mau menerima saran dari orang lain karena merasa bahwa dirinya benar dan lebih memiliki kuasa dibandingkan adiknya. Berbeda halnya dengan anak sulung, orang tua lebih memanjakan anak bungsu. Anak bungsu kerap dianggap tidak mampu menjaga diri maupun membuat keputusan sendiri. Segala sesuatu yang diinginkan oleh anak bungsu selalu dipenuhi oleh orang tua, tidak jarang anak sulung harus mengalah pada si anak bungsu.

Temuan empiris penelitian ini menyatakan bahwa terdapat perbedaan Need of Deference antara anak sulung dengan anak bungsu. Need of deference siswa yang berstatus sebagai anak sulunglebih baik daripada siswa yang berstatus sebagai anak bungsu. Selanjutnya dilakukan pengujian signifikansi masing-masing status anak, yaitu pada kelompok anak sulung dan anak bungsu dengan konseling behavioral teknik modelling. Dengan membandingkan rata-rata Need of deference kelompok siswa yang berstatus sebagai anak sulung dan kelompok siswa yang berstatus sebagai anak bungsu, ternyata rata-rata Need of deference kelompok anak sulung yang mengikuti konseling behavioral teknik modelling lebih tinggi daripada kelompok anak bungsu yang mengikuti konseling behavioral teknik modelling.

Berdasarkan kajian teoritik dari kedua status anak dan konseling behavioral teknik modelling, maka patut diduga teknik modelling lebih efektif diterapkan pada siswa yang berstatus sebagai anak sulung dibandingkan dengan anak bungsu. Konsep pemikirannya adalah teknik modelling membantu merangsang kognitif individu sehingga muncul pemahaman yang baru mengenai perilaku-perilaku yang mencerminkan pemenuhan Need of Deference yang baik dengan proses mengamati perilaku orang lain (model), sehingga muncul keinginan untuk meniru perilaku model tersebut. Pola pikir yang dimiliki oleh anak sulung dan anak bungsu berbeda dalam menanggapi suatu hal. Secara tidak langsung proses kognitif serta pemahaman yang diperoleh oleh anak sulung dan anak bungsu pastilah akan berbeda pula saat mengamati perilaku orang lain (model), sehingga perilaku yang mencerminkan pemenuhan Need of Deference yang baik yang ditampakkan setelah menyaksikan model akan berbeda pula. Anak sulung cenderung lebih sabar dan mau mendengarkan pendapat ataupun saran orang lain dibandingkan dengan anak bungsu. Anak sulung akan berhati-hati dan berpikir terlebih dahulu sebelum bertindak. Berbeda dengan anak bungsu yang cenderung egois, dan tidak mau mendengar perkataan orang lain. Dalam hal peniruan terhadap modelling tentulah anak sulung tidak semata-mata hanya meniru tetapi juga memikirkan dampak yang akan diperoleh dari hasil peniruan. Anak sulung pastinya akan lebih mudah dan lebih cepat belajar menirukan tingkah laku model dibandingkan dengan anak bungsu, hal ini dikarenakan anak sulung memiliki pemikiran bahwa apabila melakukan peniruan tersebut akan berdampak baik pada masa depannya. Sedangkan anak bungsu, dalam melakukan peniruan cenderung mengabaikan proses kognitif, yaitu bertindak tanpa berpikir.

Berdasarkan hasil yang diperoleh dapat dikatakan bahwa penerapan konseling behavioral dengan teknik modelling memiliki pengaruh yang positif terhadap need of deference siswa, baik itu pada siswa yang berstatus anak sulung maupun anak bungsu. Hal ini sejalan dengan beberapa penelitian terkait dengan konseling behavioral dengan teknik modelling. Salah satunya keberhasilan penelitian yang dilakukan oleh Putu Ayu Sopya Yanti, Ni Ketut Suarni, dan Made Setuti (2013). Penelitian tersebut dapat membuktikan bahwa konseling behavioral teknik modeling dapat mengembangkan sikap empati siswa. 
Begitu pula dengan Penelitian yang dilakukan oleh Dasita Nurfiria (2013), peneliti menggunakan teknik modeling simbolis sebagai variabel bebas, sedangkan penerimaan diri sebagai variabel terikat. Dari penelitian ini menunjukkan bahwa teknik konseling modelling simbolis efektif untuk meningkatkan penerimaan diri siswa. Penelitian yang relevan lainnya adalah hasil penelitian Robiatul Adawiyah (2012) yang dapat membuktikan bahwa konseling behavior dengan teknik modeling efektif dapat meningkatkan kemandirian belajar siswa.

\section{PENUTUP}

Berdasarkan perolehan data dari hasil pengujian dan pembahasan dalam penelitian ini, secara umum dapat disimpulkan bahwa terdapat perbedaan efektifitas teori konseling behavioral teknik modelling terhadap pengembangan Need of Deference ditinjau dari status anak dalam keluarga. Selanjutnya dapat diuraikan menjadi dua simpulan yaitu: (1) Need of deference siswa yang berstatus anak sulunglebih baik daripada anak bungsu; (2) teknik modelling lebih efektif diterapkan pada anak sulung dibandingkan dengan anak bungsu.Hal ini dikarenakan pola pikir yang dimiliki oleh anak sulung dan anak bungsu berbeda dalam menanggapi suatu hal. Dalam hal peniruan terhadap modelling tentulah anak sulung tidak semata-mata hanya meniru tetapi juga memikirkan dampak yang akan diperoleh dari hasil peniruan bagi pada masa depannya. Sedangkan anak bungsu, dalam melakukan peniruan cenderung mengabaikan proses kognitif, yaitu bertindak tanpa berpikir.

Dikarenakan berbagai keterbatasan peneliti dalam melaksanakan penelitian, disarankan pada peneliti lain untuk melakukan penelitian lanjutan yang berkaitan dengan teknik modelling dengan variabel terikat yang lain serta melibatkan sampel yang lebih luas. Mengingat bahwa masih banyak jenis kebutuhan dari teori Murray yang dapat dijadikan variabel yang merupakan bagian tidak terpisahkan dari pembentukan kepribadian siswa yang perlu dikaji pengaruhnya terhadap pengembangan dan penerapan teori konseling

\section{DAFTAR PUSTAKA}

Adawiyah, Robiatul. 2012. Pengembangan Model Konseling Behaviour dengan Teknik Modeling Untuk Meningkatkan Kemandirian Belajar Siswa SMPN 4 Wanasari Brebes. Jurnal Bimbingan Konseling. Semarang: UniversitasNegeri Semarang.

Corey., Gerald 2003. Teori dan praktek konseling dan psikoterapi. Bandung : PT. Refika Aditama.

Ferara, Ronald J. 1996. The Edwards Personal Preference Schedule as a Predictor of Success in a Collegiate Professional Pilot Training Program. Journal of Aviation/ Aerospace Education \& Research. Vol. 6.

Gunarsa, Singgih. 2004. Psikologi Perkembangan Anak dan Remaja. Jakarta: BPK.Gunung Mulia

Hall, S Calvin \& Gardner Lindzey. 1970. Theories of Personality. Second Edition. New York: John Wiley \& Sons, Inc.

Hurlock, E B. 1990. Perkembangan Anak. Jilid 2 Edisi Keenam. Jakarta: Erlangga.

Komalasari, Gantika, dkk. 2011. Teori dan Teknik Konseling. Jakarta: PT. Indek.

Nurfiria, Dasita. 2013. Efektivitas teknik modelling simbolis untukmeningkatkan penerimaan diri siswa SMA N 1 Plemahan Kabupaten Kediri. Skripsi. (Tidak Diterbitkan). JurusanBimbingan dan Konseling Fakultas Ilmu PendidikanUniversitas Negeri Malang.

Oxford Learner's Pocket Dictionary. Four Edition. 2008. University Press 
Sopya Yanti, Putu Ayu. Ni Ketut Suarni dan Made Setuti. 2013. Penerapan Model Konseling Behavioral Teknik Modeling Untuk Mengembangkan Sikap Empati SiswaKelas XC UPWSMKN 1 Singaraja. Singaraja: Jurusan Bimbingan Konseling FIP Universitas Pendidikan Ganesha. https://ejournal.undiksha.ac.id

Suarni, Ni Ketut. 2014. Metode Pengembangan Intelektual. Yogyakarta: Graha Ilmu. Sujanto, Agus dkk. 2008. Psikologi Kepribadian. Jakarta: Bumi Aksara.

Suranata, Kadek. 2010. Panduan Praktik Wawancara Konseling. Singaraja: Universitas Pendidikan Ganesha. 